JAN SAMEK

\title{
PAMIĄTKI I ZABYTKI ZWIĄZANE Z KSIĘDZEM PIOTREM SKARGA
}

Przed 384 laty, dnia 27 września 1612 roku zmarł w Krakowie, w klasztorze jezuitów przy kościele ŚS. Piotra i Pawła, ksiądz Piotr Skarga Powęski. Znakomity kaznodzieja i utalentowany pisarz, inicjator budowy tegoż kościoła.

Ostatnie miesiące życia Skargi upłynęły spokojnie. Po rezygnacji z pobytu przy królu Zygmuncie III Wazie na dworze w Warszawie, w 1612 roku przybył do Krakowa, gdzie, jak pisze monografista jezuitów przy kościele SŚ. Piotra i Pawła w Krakowie, ksiądz Stanisław Załęski: ...,,Dopóki sił starczyło, odprawiał codziennie mszę św., resztę dnia na modlitwę, na czytanie ksiąg Pisma św. i Ojców Kościoła obracal, a dla rozerwania umysłu i uniknięcia próżnowania albo kałamarze robił, albo świece, albo oprawy do ksiąg, albo szkatułki pisarskie, chustki szył dla nowicjuszów, a przedtem jeszcze koszule, chustki na swą potrzebę sam rabiał".

Przed śmiercią Skarga wysłał do Częstochowy, jako ofiarę, wielką w'oskową, własnoręcznie odlaną świecę przed ołtarz Matki Boskiej. Nastẹpnego dnia po śmierci, trumnę umieszczono na katafalku w głównej nawie kościola SS. Piotra i Pawła, gdzie przy obecności wielu jezuitów, księży, szlachty i mieszczaństwa, kazanie po mszy żalobnej wygłosil inny sławny mówca, dominikanin Fabian Birkowski, posługując się jako motywem przewodnim tekstem: „Powstał Eliasz jako ogień, i słowo jego jako pochodnia gorzało".

Trumnę ze zwłokami księdza Piotra Skargi złożono w krypcie (grobowcu zakonnym) przed ołtarzem głównym kościoła. Kazanie, w którego drugiej części stwierdzono, że Skarga zrealizował ideał kapłana ukazany przez Eliasza, zostało jako mowa żałobna kilkakrotnie ogłoszone drukiem. 
Po wielkim kaznodziei pozostały liczne dzieła, przede wszystkim $\dot{Z} y$ woty swietych, Kazania i niezwykle ważna praca $O$ jedności Kościola Bożego, wydana drukiem w 1577 r., która przyczyniła się walnie do zawarcia Unii Brzeskiej, i kolejna praca dotycząca tej samej tematyki $\mathrm{z}$ roku 1597. W niedługim czasie będziemy obchodzić setną rocznicę zawarcia Unii, o czym już teraz należy pomyśleć.

Dziś jednak stawiamy sobie pytanie, jakie pamiątki i zabytki zachowały się lub powstały $\mathrm{w}$ związku $\mathrm{z}$ działalnością polityczną, co nie wahamy się powiedzieć, społeczną i twórczą ks. P. Skargi. Pod tym określeniem rozumiemy pozostałe dzieła po wielkim kaznodziei.

Przegląd tych zabytków pozwoli bowiem na określenie w jakich czasach odżywała pamięć o Skardze, jakie znalazła odbicie w sztuce, co moźe zostać również skonfrontowane $\mathrm{z}$ zainteresowaniem osobą Skargi w badaniach $\mathrm{z}$ różnych dziedzin filologicznych, społecznych i politycznych.

Przede wszystkim wymienić należy portrety. Nie należą one do unikatów choć, stwarzają trudności przy datowaniu i pochodzą raczej z czasów po śmierci kaznodziei. Wymienić tu należy takie zabytki, jak portret Piotra Skargi określony w Katalogu Zabytków Miasta Krakowa jako barokowy, datowany nie bez wątpliwości na wiek XVII, przechowywany w klasztorze jezuitów przy kościele Św. Barbary w Krakowie. Wyjaśnić pragniemy, że Kraków zostal wyznaczony na miejsce badań pamiątek po Piotrze Skardze, bowiem najwięcej się ich tutaj znajduje.

Drugi portret Skargi włączono w liczne wizerunki zdobiące tzw. salę portretową w Domu, zalożonego przez Piotra Skargę Arcybractwa Miłosierdzia i Banku Pobożnego. Ściany tejże sali, znajdującej się na pierwszym piętrze narożnego domu przy ul. Siennej (nr 5) i Stolarskiej (nr 2) pokryto portretami osób związanych z Arcybractwem Milosierdzia, pochodzącymi z różnych okresów. Są to siedemnastowieczne i późniejsze repliki oraz kopie, stanowiące jedyne $w$ swoim rodzaju wnętrze ściśle związane $z$ instytucją zalożoną przez ks. Piotra Skargę. Umieszczony tam portret Skargi ma podobny charakter jak u jezuitów i zapewne powstał także po śmierci kaznodziei, przemalowany w 1864 przez Józefa Cholewicza. W tejże sali, będącej Izbą Bracką, zwaną także Salą Obrad, w 1884 roku Kazimierz Pochwalski wykonal duży plafon ze sceną ks. Skargi w otoczeniu ubogich i współzałożycieli Arcybractwa Miłosierdzia, Mikołaja Zebrzydowskiego i Doroty Barzyny.

Można powiedzieć nawet, że portret ten reprezentuje pewien typ powszechny w portretach zakonnych. Najpierw jednak pragnę wyjaśnić, że w ramach tzw. portretu sarmackiego istnieje osobny, specyficzny typ portretów duchownych, w tym szereg grup nacechowanych monochromatycznym kolorytem przy realiźmie właściwym dla sarmackich wizerunków. 
Pracując nad tym zagadnieniem mogę określić wizerunki Skargi jako należące do nieco większej grupy.

Grupę tę cechuje przedstawienie zmarłych w nieco więcej niż pól postaci, $\mathrm{z}$ twarzą lekko zwróconą $\mathrm{w}$ prawo i modlitewnie zlożonymi rękoma. Przedmiotem adoracji jest Krucyfiks stojący przed modlącą się osobą. Niekiedy obok Pasji wyobrażone bywają takie przedmioty jak książka, dzwonek czy zegar. Podkreślić należy, że w znanych portretach Skargi występują cechy powtarzane na późniejszych jego wizerunkach, a mianowicie ascetyczna twarz, dość długie włosy i wydatny nos. Jest to niewątpliwie wynik albo oparcia się na wcześniejszych wizerunkach, albo tradycja utrzymująca się w zakonie. Oczywiście nie przedstawiamy tu pełnego zestawu wizerunków kaznodziei, bowiem wykraczałoby to poza ramy pracy. Niewątpliwie pochodzące z XVII wieku portrety, jak zasygnalizowano, oddziaływały na dziewiętnastowieczną ikonografię kaznodziei.

Pamiątki związane ze Skargą należą do unikatów. Najważniejszym $\mathrm{z}$ nich jest wzmiankowana przez Załęskiego we wspomnianej już pracy z roku 1896, w Katalogu zabytków Sztuki Miasta Krakowa cz. III, wydanym w roku 1978, oraz wspomniana w artykule Juliusza Chrościckiego trumienka, zwierająca szczątki księdza Piotra Skargi. Przeniesiono do niej resztki zwlok przy porządkowaniu grobowców w roku 1695. Trumienka owa powtarza kształty trumny zwykłych rozmiarów, ale jest mniejsza, znacznie krótsza. Wykonano ją z cyny, o przekroju trapezowym, który to przekrój zastosowano także dla wieka. Została opublikowana w rysunku przez wspomnianego księdza Stanisława Załęskiego. Pierwsze zdjęcia wykonano zapewne do Katalogu Zabytków i opublikowano je w tymże Katalogu cz. III i artykule Juliusza Chrościckiego w „Roczniku Historii Sztuki" w 1973 roku. Poza zaakcentowaniem narożników trumny listwami i fryzami z liśćmi, zdobi ją skromna, ale pełna wyrazu dekoracja. Składają się nań cztery niewielkie lwy, na których wsparto trumnę oraz duże antaby w kształcie lwich paszczy na części dolnej i mniejsze, o takiej samej formie na części górnej. $\mathrm{Na}$ trumience umieszczono napis, który warto za Załęskim zacytować w thumaczeniu opublikowanym przez Ambrożego Grabowskiego: „Ta trumna ołowiana obejmuje złotego królów złotoustego, wielebnego sługę bożego O. Piotra Skargę. Zasługuje na ubolewanie, że nie w większej trumnie zawarty jest ten, który dwory monarchów apostolskimi cnotami, świat chrześcijański gorliwością, biblioteki uczonych nauką, Towarzystwo Chwałą, duszą niebo zapełnil, „lecz ten zakonnego ubóstwa przykładny czciciel, i tym grobem, żyjąc, byłby pogardził, który pobożny pierwszego w Królestwie kaznodziei wielbiciel O. Stanisław Bielicki Tow. Jez. kosztem I. O. Katarzyny z Sobieskich Radziwiłłowej obmyślił r. 1695”.

Jak $z$ powyższego i inskrypcji wynika, trumienka na której znajdują się nie zidentyfikowane znaki konwisarskie, ufundowana została przez 
siostrę króla Jana III Sobieskiego Katarzynę, wdowę po Michale Kazimierzu Radziwille. Należy tutaj dodać, że Juliusz Chrościcki wyjaśnił, że ks. Piotr Dunin w kazaniu po śmierci Katarzyny Radziwiłłowej popełnił pomyłkę mówiąc, iż trumienka została ufundowana w 1694 roku.

W szerszym aspekcie trumienka Skargi należy do wyrobów konwisarskich, które tylko jeśli chodzi o trumny w grobach królewskich na Wawelu zostały dokładnie zbadane. Temat to wprawdzie szczególny, ale nie można pomijać faktu, że kształty, dekoracje i programy ikonograficzne trumien wykonywanych w Polsce w okresie baroku, nie są dotąd zupełnie zbadane. Problem ten zawiera $w$ sobie wiele walorów historycznych, aspektów artystycznych, jak i stanowi źródło wiedzy o kulturze religijnej tej epoki.

$\mathrm{Na}$ dalsze pamiątki związane $\mathrm{z}$ ks. Piotrem Skargą, dzieła sztuki zainspirowane jego działalnością, czekać przyjdzie 150 lat.

Dopiero bowiem wiek XIX z jego pietyzmem dla przeszłości, zrywami niepodległościowymi i charakterystycznym historyzmem spowodowal powrót do tematyki związanej z ks. Piotrem Skargą. Cofając się w czasie, rzecz zrozumiała, lata zaborów i kasaty zakonu jezuitów w roku 1773 nie sprzyjały wznosżeniu pomników jego wybitnym nawet przedstawicielom. Ale dzieło Skargi trwało. Stale ukazywały się nowe edycje Żywotów i Kazań. Czynne było nadal Arcybractwo Miłosierdzia i Bank Pobożny. Wlaśnie z inicjatywy tegoż Arcybractwa w 1844 r. umieszczono w kościele ŚŚ. Piotra i Pawła w Krakowie w południowej ścianie prezbiterium pamiątkową tablicę z czarnego marmuru, w kamiennym, rzeźbionym obramowaniu. Mieści ona nawiązujący do portretów epitafijnych wizerunek Piotra Skargi, namalowany na blasze na złotym tle, oraz pamiątkowy napis:

X. Piotr Skarga Powęski

urodzony roku 1556 w Mazowszu

Kaznodzieja Króla Zygmunta III

Założyciel Arcybractwa Miłosierdzia i Banku pob., którego cnót i zasług pochwała w czynach

i pismach jego jest zawarta

Zmarł d. 27 września 1612 r. Krakowie

w tej świątyni spoczywa.

Arcybractwo Miłosierdzia i Banku pobożnego

Patryarsze swemu

Pomnik ten w 1844 roku polożyło.

Autorem tablicy był rzeźbiarz ze znanej rodziny Gallich, którą sprowadził do Polski król Stanisław August Poniatowski dla reaktywowania kamieniołomu w Dębniku koło Czernej. Tablicę pamiątkową wykonał Jan Nepomucen Galli, który wykuł także w kościele ŚS. Piotra i Pawła epitafium poświęcone swemu ojcu, także rzeźbiarzowi, Leonardowi. 
Poszerzając powyższe informacje dodajmy, że rodzina Gallich, krótko omówiona przez Władysława Tatarkiewicza w pracy o czarnym marmurze, zasługuje na monografię, jako że wykonali oni sporo dzieł, poza innymi pracami, nagrobków i epitafiów, w tym pierwszy w Krakowie pomnik Mikołaja Kopernika z 1822 r., w kolegiacie Św. Anny, epitafium malarza Piotra Michałowskiego (zm. w 1855 r.) w kościele Mariackim w Krakowie, a także inne nagrobki, w tym w formie kolumn w tejże bazylice i przy kościele Najświętszego Salwatora na Zwierzyńcu.

Chyba niedoceniane dotąd znaczenie miała dla przybliżenia społeczeństwu podzielonej na zabory Polski postaci kaznodziei jedna z wczesnych ogromnych kompozycji Matejki Kazanie Skargi. Obraz ten, dziś znajdujący się poza Krakowem, w Muzeum Narodowym w Warszawie, jak zwykle u Wielkiego Mistrza, poprzedziły liczne szkice, wynikające $\mathrm{z}$ tak charakterystycznej dla malarza chęci zastosowania licznych realiów z dawnych czasów (dziś w zbiorach prywatnych i Muzeum Narodowego w Krakowie w Domu Matejki). Kazanie Skargi (powstałe w 1864 roku), w którym Matejko przedstawił współczesne kaznodziei postacie, o wielkiej sile ekspresji, oddziaływało silnie na odbiorców. Można zaryzykować twierdzenie, że od namalowania tego ogromnego dziela, Polacy myśląc i mówiąc o Skardze, widzą go oczami Matejki. Ale powstawały też $\mathrm{i}$ inne wyobrażenia niezapomnianego kaznodziei.

W czasach, gdy zamek na Wawelu zajęty był przez wojska austriackie, w 2. połowie XIX wieku powstała, budząca wiele wątpliwości (nie zrealizowana, ale ciekawa $\mathrm{z}$ historycznego punktu widzenia), idea utworzenia z kościola ŚS. Piotra i Pawła narodowego panteonu. Lączyło się to z planami przeniesienia tu pomników królewskich. Na szczęście nie doszło do jej realizacji, ale w nadającym się ze względu na wspaniałe, zwieńczone kopulą wnętrze, powstało dziewięć pomników z marmuru i brązu, upamiętniających glównie zasłużonych Polaków, jak Kajetana Florkiewicza, senatora i marszałka, czy Maurycego Drużbackiego, a także ks. Piotra Skargę.

Jest to okazała rzeźba na wysokim cokole, przedstawiająca kaznodzieję w pozycji stojącej, z prawą ręką wspartą na stosie swych dzieł z tytułami na grzbietach, ustawionych na cokole ozdobionym herbem Polski i godłem jezuitów, lewą złożoną na piersi. Artysta przedstawił zmarłego w stroju zakonnym, powtarzając charakterystyczne cechy twarzy. Pomnik, z którego tchnie nastrój powagi, a twarz emanuje kaznodziejskim natchnieniem, jest sygnowany dzielem znanego rzeźbiarza Oskara Sosnowskiego, wykonanym w Rzymie w 1869 roku. Sprawienie tak wspaniałego pomnika jest niewątpliwie wyrazem zainteresowania i pełną nobilitacją zasłużonego jezuity. Przypomnijmy, że Tomasz Oskar Sosnowski należał do najwybitniejszych artystów polskich XIX wieku (żył w latach 1810-1888). Około 1846 roku osiadł w Rzymie, gdzie zajął poważne stanowisko profesora rzeźby 
w Akademii św. Łukasza. Jego dzieła cechuje przynależność do nurtu akademickiego klasycyzmu, przy czym nie przeszkadzało to artyście w wykonywaniu realistycznych popiersi portretowych. Sosnowski zasadniczo związany był, poza Rzymem, z Warszawą, gdzie wykonał pomnik Tadeusza Czackiego w kościele Wizytek w 1861 roku. W Krakowie znanym jego dziełem jest pomnik Jadwigi i Jagiełly na "Górce" na Plantach (ogród „Florianka”), posiadający eklektyczny charakter.

W XIX wieku minęło także 300-lecie założenia przez Skargę Arcybractwa Miłosierdzia. Część szat ks. Piotra Skargi wydobyto z trumienki cynkowej i umieszczono w drugiej, oraz dano podstawę marmurową w formie nawiązującej do katafalku. Poza religijnymi uroczystościami i publikacjami wybity zostal pamiątkowy medal poświęcony Skardze. Dla omówienia tego numizmatu poświęcimy jednak osobną pracę.

Wiek XIX był w Krakowie, od wielkiego pożaru w 1850 roku, okresem odnawiania i rekonstruowania zabytków. Mialo to oczywiście $\mathrm{i}$ inne przyczyny poza ich złym stanem zachowania. Chodziło o ukazanie, a nawet upiększenie pomników świetności Rzeczypospolitej. Odnowiono groby królewskie, utworzono też w katedrze na Wawelu krypty na pomieszczenia sarkofagów Adama Mickiewicza i Juliusza Słowackiego.

Z inicjatywy Józefa Lepkowskiego, archeologa, historyka sztuki i konserwatora (1890) powstały również Groby Zasłużonych na Skałce.

Nadszedł i czas na odnowienie krypt w kościele ŚŚ. Piotra i Pawła w Krakowie. Prace podjęto $\mathrm{z}$ inicjatywy wspomnianego Józefa Lepkowskiego, dzięki funduszom Elżbiety z Grabowskich Czosnowskiej, z początkiem lat osiemdziesiątych XIX wieku. Kryptę mieszczącą prochy kaznodziei uporządkowano, wykonano nowe schody kamienne $\mathrm{z}$ żelaznymi drzwiami z napisem „Grób Skargi”. Powstała także inicjatywa, aby w każdą rocznice śmierci księdza Piotra odprawiano w krypcie nabożeństwo żałobne. Msza żałobna miała miejsce w roku 1884 w obecności bpa krakowskiego Albina Dunajewskiego i nie będących już gospodarzami kościoła - jezuitów.

Wyraźnym dowodem wielkiego uznania dla działalności Piotra Skargi jest wykonanie w roku 1886, na zamówienie dra Henryka Jordana, popiersia kaznodziei z bialego szwajcarskiego marmuru, z przeznaczeniem do parku Jordana.

Popiersie to należało do specjalnego założenia w centrum parku, zwanym „,kołem pomnikowym”, przy którym ustawiono 16 rzeźb. Były to pomniki: Jana Dlugosza, ks. Konstantego Ostrogskiego, Mikolaja Kopernika, Jana Tarnowskiego, Jana Kochanowskiego, ks. Piotra Skargi, Jana Zamoyskiego, Jana Karola Chodkiewicza, Stefana Czarnieckiego, Stanisława Źółkiewskiego, Stanisława Jana Jabłonowskiego, ks. Augustyna 
Kordeckiego, Konstantego Wasyla Ostrogskiego, Józefa Hauke-Bosaka, Zygmuna Krasińskiego.

Skarga znalazł się więc pośród najbardziej znanych i zasłużonych Polaków. Obecnie, po zniszczeniu części pomników w czasie wojny i wykonaniu kilku nowych, popiersie Skargi znajduje się w bocznej alejce, gdzie stoją na postumentach popiersia: Mikołaja Kopernika, Władysława Reymonta, ks. Augustyna Kordeckiego, Jana Tarnowskiego, Konstantego Ostrogskiego, Józefa Hauke-Bosaka i Zygmunta Krasińskiego. Dodać wszakże należy informację o wykonawcy pomnika Piotra Skargi w parku Jordana, który opatrzył swe dzieła sygnaturą A. Daun i datą 1887. Popiersie doktor Henryk Jordan ofiarował gminie i stanęło ono w parku w 1889 roku jako jedno z pierwszych ośmiu, którymi były wyobrażenia: Długosza, Kochanowskiego, Zamoyskiego, Czarnieckiego, Tarnowskiego, Kopernika i Kościuszki.

Alfred Daun (1854-1922), urodzony w Baranowie, zmarły w Krakowie, był zdolnym rzeźbiarzem. Uczeń Walerego Gadomskiego, a także Stanisława Wyspiańskiego, docent i profesor w Krakowskiej Akademii Sztuk Pięknych. Jego mecenasem był Henryk Jordan. Niestety, prace Dauna w parku Jordana nie wzbudziły entuzjazmu. Prowadził ożywioną działalność dydaktyczną, między innymi pracowali u niego Ksawery Dunikowski i Jan Szczepkowski.

Z monumentalnych rzeźb na stałe weszły do krajobrazu plant Krakowa jego Lilla Weneda (1888) oraz Grażyna (1886). Popiersie roboty Dauna nie bylo jednak ostatnim z ważniejszych pomników Piotra Skargi w Krakowie.

W przedsionku prowadzącym do krypty w kościele ŚŚ. Piotra i Pawła w Krakowie umieszczono, wyróżniające się dobrym poziomem artystycznym, popiersie wykute w białym marmurze w 1912 roku przez rzadko wzmiankowanego rzeźbiarza, Tomasza Tombińskiego.

Z malowideł, od których odeszliśmy zajmując się rzeźbą, przypomnieć należy zdobiącą sufit scenę w sali portretowej Arcybractwa Miłosierdzia (przy ul. Siennej 3), która zawiera także przedstawienie wielkiego kaznodziei. Autorem był malarz krakowski i konserwator, Stanisław Pochwalski.

Przedstawienie księdza Piotra Skargi znajdujemy często na dość szczególnych zabytkach. Otóż w roku 1900, w 500-lecie odnowienia Uniwersytetu Jagiellońskiego przez króla Władysława Jagiełłę, otrzymał w darze od miasta Wilna ówczesny Wydział Filozoficzny okazałe berło, zakończone posążkiem księdza Piotra Skargi w całej postaci oraz medalionami profesorów Uniwersytetu Wileńskiego: Jana Sniadeckiego i Joachima Lelewela, oraz herbami Polski, Jagiellonów i Uniwersytetu Jagiellońskiego. 
W tym miejscu, choć można by to uczynić raczej przy malarstwie, warto wspomnieć grafiki przedstawiające księdza Piotra Skargę, które często umieszczano, zapewne w oparciu o wcześniejsze wzmiankowane portrety w licznie wydawanych w XIX wieku, a także pierwszym dziesięcioleciu XX wieku, dzielach sławnego kaznodziei. Przykładem może być rycina przedstawiającą Skargę w pól postaci, jak na portretach, modlącego się przed krucyfiksem, na którym umieszczono ponadto rękopis, kalamarz $\mathrm{z}$ piórem i księgi; rycina ta umieszczona została w Żywotach Świętych pióra Skargi, wydanych w Krakowie w drukarni W. L. Anczyca i spółki w 1882 roku.

Przedstawione zabytki, a nie sugerujemy, aby była to pełna ikonografia ks. Piotra Skargi, bo nie taki jest temat pracy - unaoczniają dwa ważne zjawiska.

Pamięć o sławnym kaznodziei żyła w wieku XVII i niewątpliwie na początku następnego stulecia. Potem zaobserwować możemy wyraźną przerwę. Jak wolno się domyślać, związane to było $z$ sytuacją zakonu jezuitów.

Początek nowego zainteresowania Skargą w dobie, gdy istniały tak wielkie spory o przyczyny upadku Rzeczypospolitej, przyniósł z jednej strony jubileusz Arcybractwa Miłosierdzia, z drugiej zaś - niewątpliwie powstanie monumentalnego obrazu Jana Matejki. Od tego czasu wykonano dla Krakowa trzy pomniki związane z osobą Piotra Skargi, dzieła najwybitniejszych rzeźbiarzy. Druga połowa XIX i początek XX wieku, a właściwie żyjący wówczas ludzie o wielkim sercu, dobrze zasłużyli się dla podtrzymania pamięci o Skardze.

Jak zapisze się $w$ tej dziedzinie koniec naszego stulecia i początek wieku XXI, poza zorganizowaną $\mathrm{z}$ inicjatywy autora tego referatu sesją naukową? Oby zapisal się dobrze.

Wybrana literatura przedmiotu:

Budowle świeckie. W: Katalog zabytków sztuki w Polsce. Miasto Kraków. Mps w IS PAN.

Kościoly i klasztory Sródmieścia. 1-2 pod red. A. Bochnaka i J. Samka. Warszawa 1971 (cz. 2), 1978 (cz. 3).

J. Kuciel, Park im. dr. H. Jordana w Krakowie jako przyklad placówki wychowania pozaszkolnego dzieci i mlodzieży. Kraków 1989. Mps w posiadaniu autorki.

J. Samek, Oltarz glówny w kościele ŚŚ. Piotra i Pawla w Krakowie, geneza koncepcji ikonograficznej. „Zeszyty Naukowe UJ”. Z. 5. Kraków 1967. 
Slownik Artystów polskich i obcych w Polsce dzialających. Malarze, rzeźbiarze, graficy. Hasło: Daun Alfred. T. 2, Warszawa 1975. Hasło: Korpal Stefan. T. 4, Wrocław 1986.

S. Zalęski, OO. Jezuici przy kościele Św. Piotra i Pawla w Krakowie. Nowy Sącz 1896.

Praca o pamiątkach i zabytkach związanych z ks. Piotrem Skargą w pierwotnej wersji referowana była na Sesji zorganizowanej przez autora na Papieskiej Akademii Teologicznej w Krakowie, Wydzial Historii Kościola.

Pani mgr Joannie Kuciel składam podziękowania za udostępnienie materialów dotyczących parku Jordana.

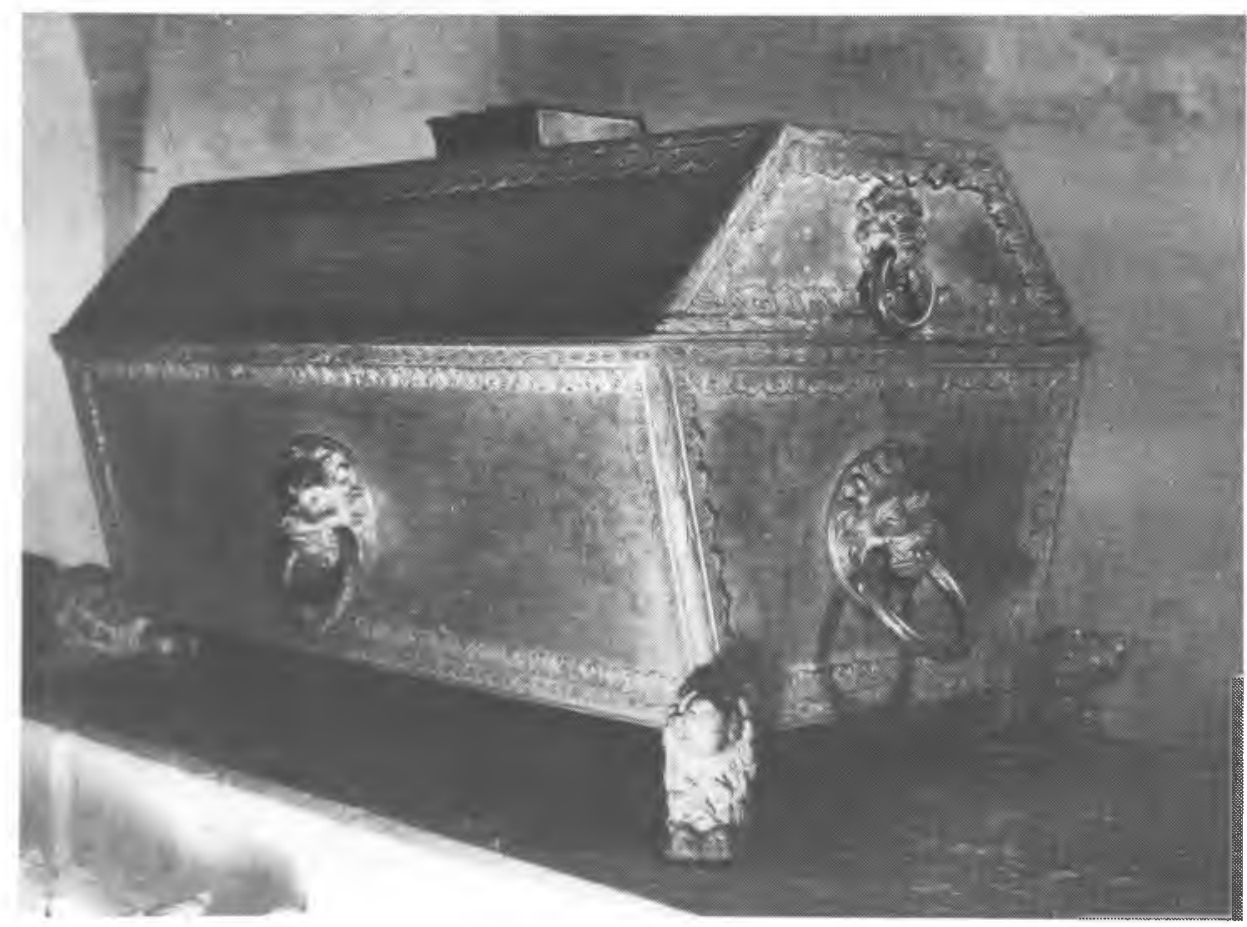

Trumienka cynkowa na prochy ks. Piotra Skargi z 1695 roku w kościele ŚŚ. Piotra i Pawła w Krakowie (fot. ze zbiorów IS PAN) 


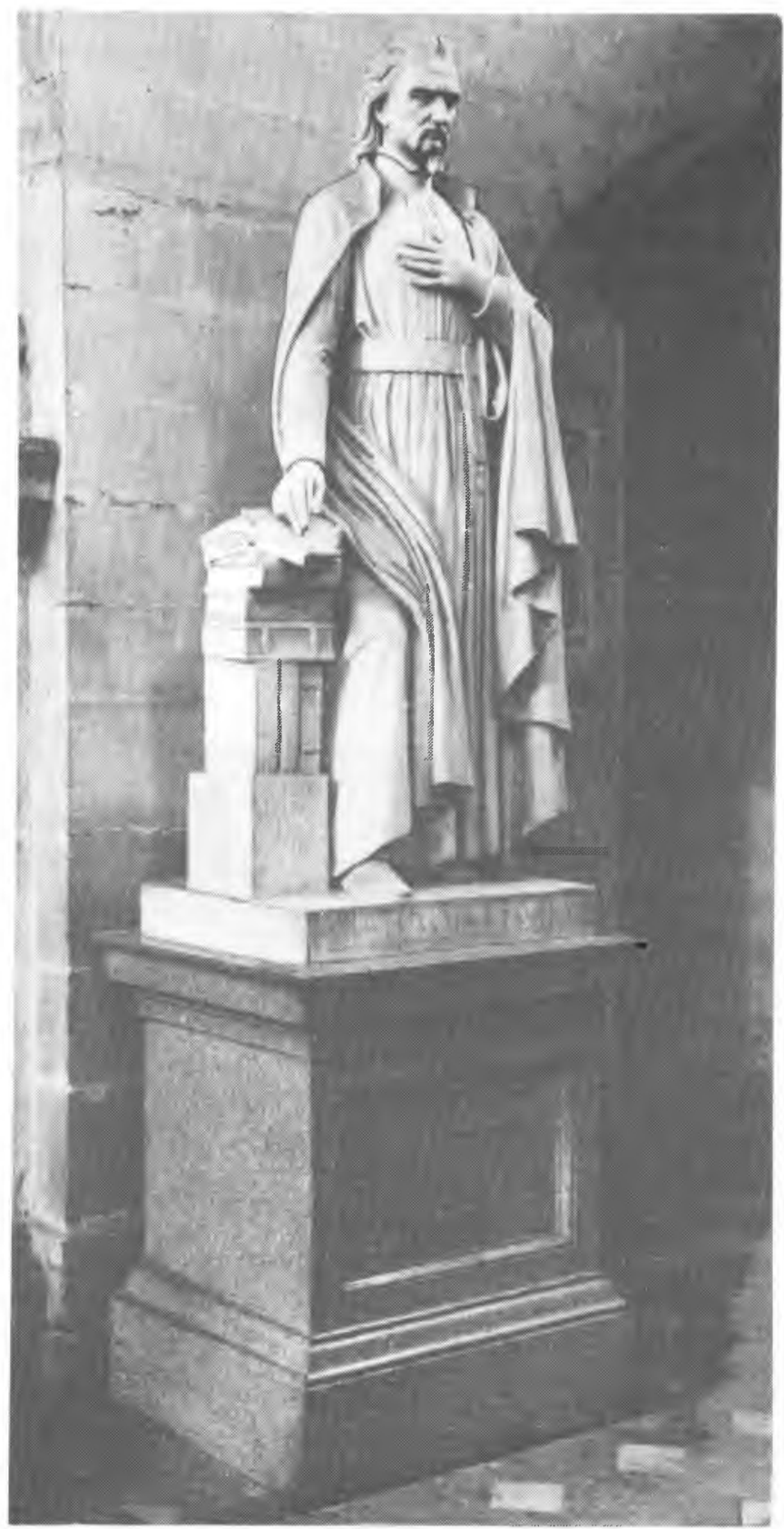

Pomnik ks. Piotra Skargi z 1869 roku w kościele ŚŚ. Piotra i Pawła w Krakowie (fot. J. Langda) 


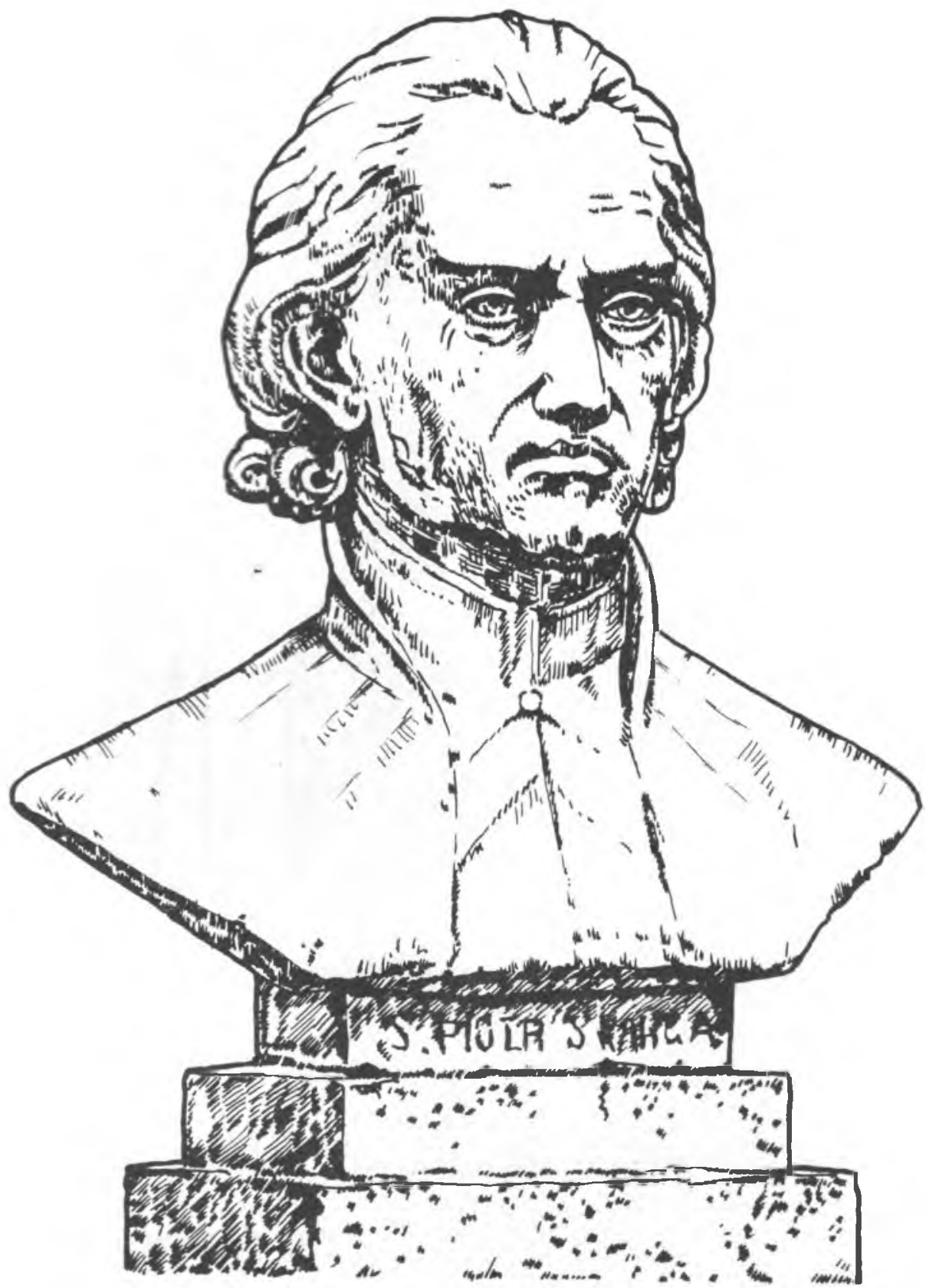

Popiersie ks. Piotra Skargi w parku Jordana w Krakowie z 1886 roku (rys. E. Samek) 


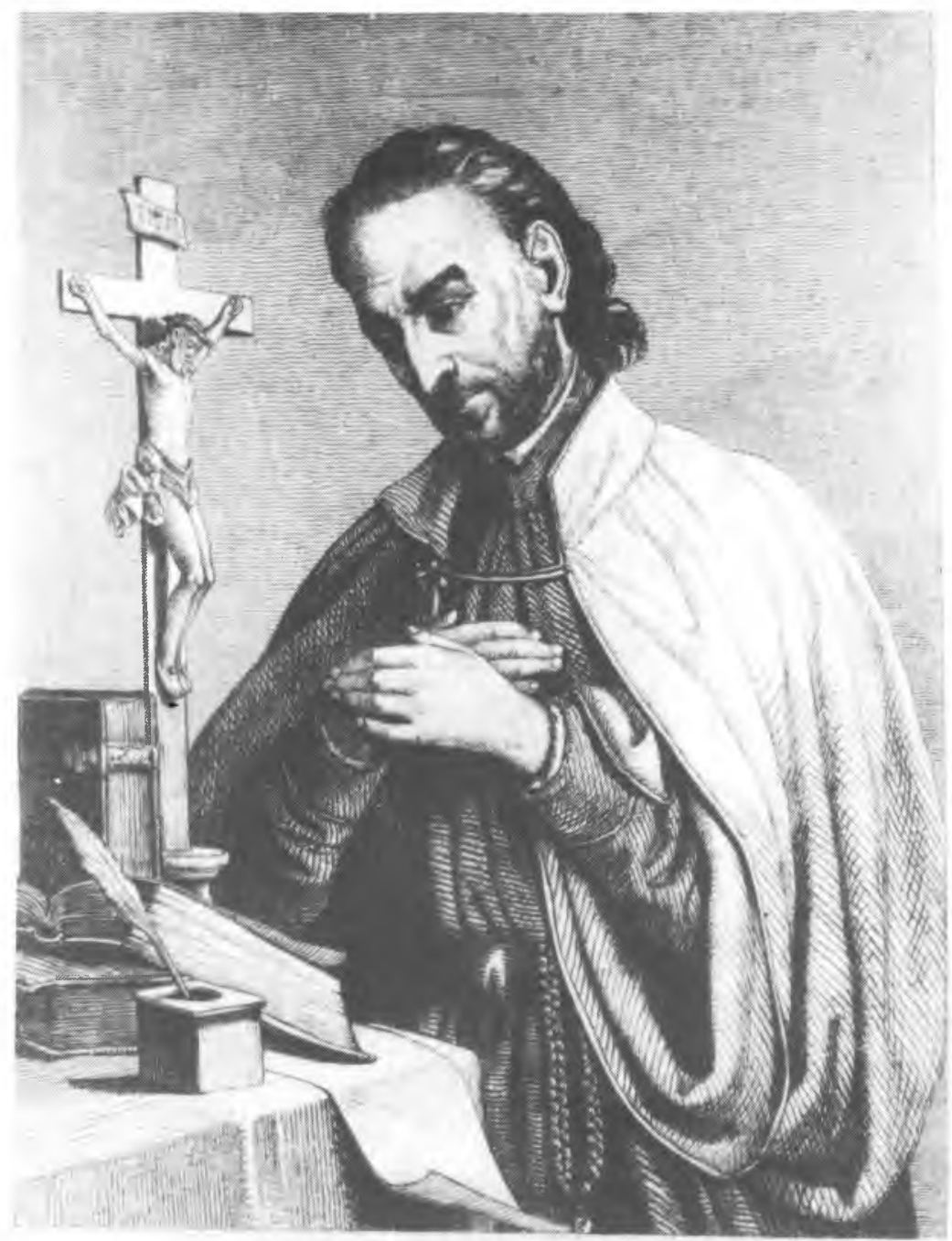

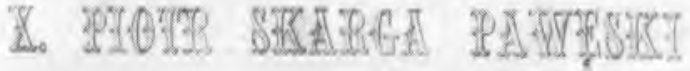

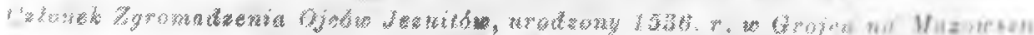

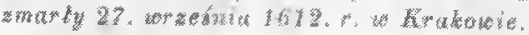

Rycina przedstawiająca ks. Piotra Skargę sprzed 1866 roku (fot. M. Stec) 


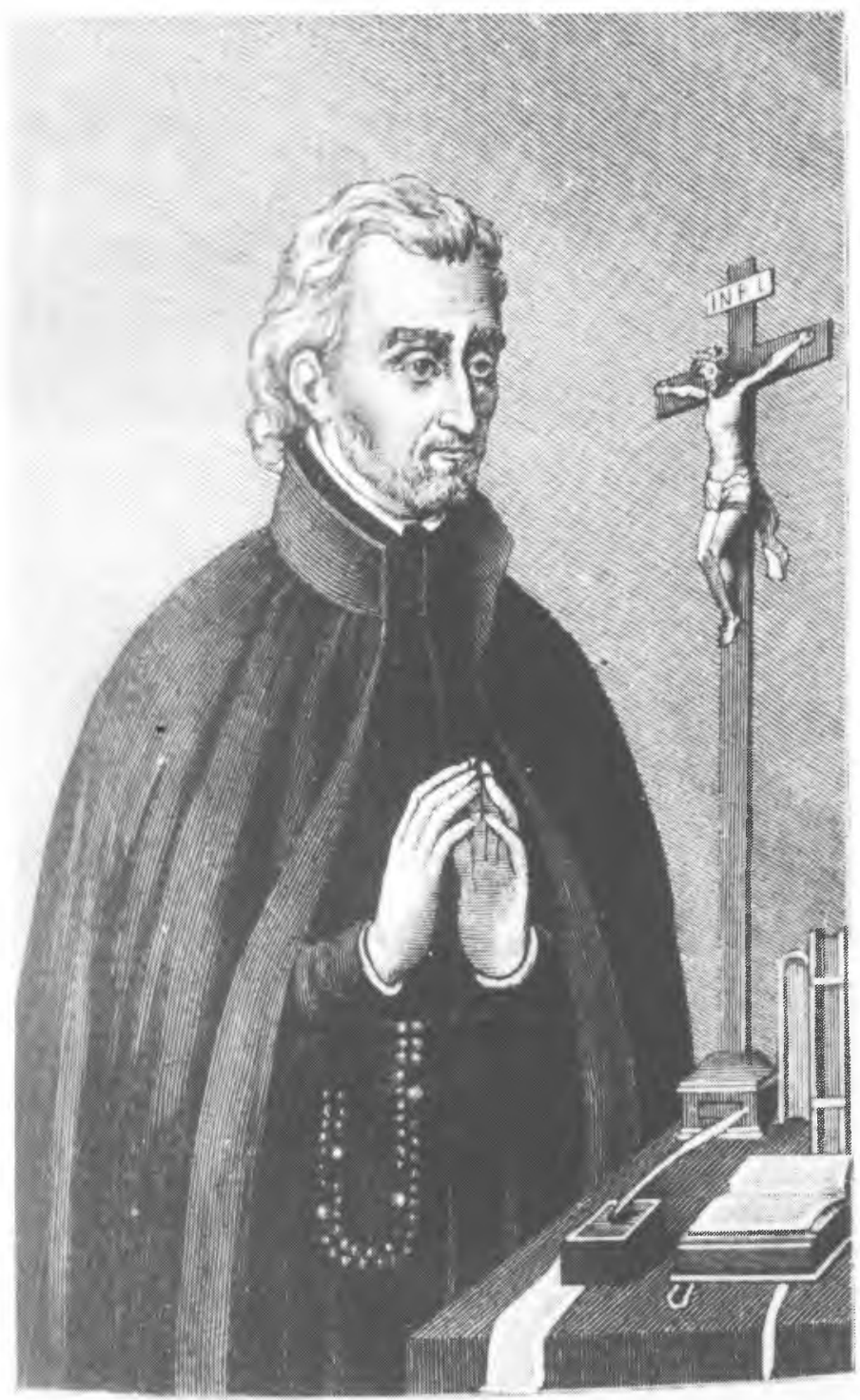

ks. PUTK SKARGA.T.J.

Rycina przedstawiająca ks. Piotra Skargę sprzed 1882 roku (fot. M. Stec), wg Żywotów Świętych wydanych w Wiedniu w 1860 roku nakładem OO. Mechitarzystów 